\title{
Electrochemical Development of Ni-Cu Electrodes by Direct and Pulse Current Coating in Ethanol Electro-oxidation for DEFC
}

\author{
Sujit Kumar Guchhait* and Subir Paul \\ Metallurgical and Material Engineering Department and Centre of Excellence, \\ TEQIP-II, Jadavpur University, Kolkata-700032, India
}

Received February 22, 2017; accepted September 2, 2017

\begin{abstract}
The electrocatalytic property of electrode materials is the key for getting high cell current and low overvoltage of a fuel cell from fuels electro-oxidation. The bridge between laboratory scale fuel cell development and its fully commercialization is the development of inexpensive but energetic electrode materials. The catalytic actions of an electrode substrate are strongly influenced by the morphology and the grain fineness of the deposited materials. The present investigation aims at finding the effect of electrode deposition mode viz. direct current and pulse current coating, to produce an electrodeposited substrate that can deliver the highest current in a direct ethanol fuel cell. Nickel (Ni) is one of such non precious materials which has been produced through electro synthesis by both pulse current (PC) and direct current (DC) coating. It has been found that the morphology of the deposited is highly influenced by the current density, duty cycle, electrolyte chemistry and right selection of deposition potential on the cathodic polarization curve around the Tafel lines. Electrochemical characterization has been done by cyclic voltammetry $(\mathrm{CV})$, chronoamperometry $(\mathrm{CA})$ and potentiodynamic polarization (PD) studies. The substrate of the electrodeposited material has also been characterized by X-Ray Diffraction analysis (XRD), Energy Dispersive X-Ray Analysis (EDXA) and Scanning Electron Microscope (SEM). It has also been found that the electro synthesis by pulse current coating at pre-selected deposition potential, right at the end of Tafel region, at $40{ }^{\circ} \mathrm{C}$ temperature and 150 second deposition time, gives the highest delivering current of ethanol fuel oxidation.
\end{abstract}

Keywords: Direct ethanol fuel cell, inexpensive Ni-electrode, direct and pulse current coating, cyclic voltammetry, XRD, EDXA, SEM.

\footnotetext{
*Corresponding author. E-mail address: sujitguchhait.chem@gmail.com,dr_spaul@yahoo.com
} 


\section{Introduction}

The demand for energy is growing every day, due to fast urbanization, fulfillment of our daily needs and the progress of world economy. The energy demand has been mostly fulfilled by conventional energy resources, such as coal, natural gases, etc.

However, the energy harvesting from this resources creates a lot of polluting gases, hazardous substances which have a very harmful impact on global environment, leading to health hazardous problems, not acceptable to the governments of developed and developing nations. So, the production of pollution free renewable energy at an economically viable price is a huge challenge to researchers and scientists. A fuel cell, operated with renewable fuels, is such a kind of alternative technology, to produce clean renewable energy [1]. In the fuel cell, fuel is electrochemically oxidized at the electro catalytic anode surface, knocking the electrons from the fuel, and transferring them in the form of current through the electrode and current collector to the external circuit. The energy conversion efficiency, by this route of thermal to mechanical energy, is not limited by the Carnot cycle heat engine, and hence, is very high. Direct Ethanol Fuel Cell (DEFC) is one of the most promising electrical energy producing units from clean renewable energy technology [2-6]. In DEFC, liquid fuel ethanol has certain advantages over other biofuels, such as methanol. Ethanol is nontoxic, has low vapor pressure, is easily transported, and can be effortlessly produced in great quantities by fermentation of sugar-containing agricultural materials [7-10]. Moreover, electrochemically oxidation of ethanol by an anode material produces carbon dioxide $\left(\mathrm{CO}_{2}\right)$, releasing 12 electrons, according to the following reactions [6]:
Anode: $\mathrm{CH}_{3} \mathrm{CH}_{2} \mathrm{OH}+12 \mathrm{OH}^{-} \rightarrow 2 \mathrm{CO}_{2}+9 \mathrm{H}_{2} \mathrm{O}+12 \mathrm{e}^{-}$

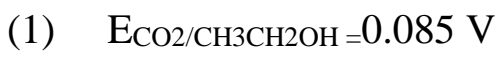
Cathode: $\mathrm{O}_{2}+4 \mathrm{H}^{+}+4 \mathrm{e}^{-} \rightarrow 2 \mathrm{H}_{2} \mathrm{O}$

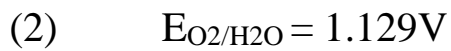

\section{Overall reaction: $\mathrm{CH}_{3} \mathrm{CH}_{2} \mathrm{OH}+3 \mathrm{O}_{2} \rightarrow 2 \mathrm{CO}_{2}+3 \mathrm{H}_{2} \mathrm{O} \quad$ (3) $\mathrm{E}_{\mathrm{O} 2} / \mathrm{CH} 3 \mathrm{CH} 2 \mathrm{OH}=1.144 \mathrm{~V}$}

Pt or Pt base electrodes with high electrocatalytic activities are generally used for the ethanol electro oxidation, but this is a restricted process, due to its high cost and low availability [11-15]. Various works have been done to incorporate some non-Pt based metal oxides viz. $\mathrm{CeO}_{2}, \mathrm{Co}_{3} \mathrm{O}_{4}, \mathrm{Mn}_{3} \mathrm{O}_{4}$ [16-18]. Authors have been also working on developing non $\mathrm{Pt}$ based electrode materials for fuel cell electrodes. It was found that inexpensive $\mathrm{ZnO}-\mathrm{Al}_{2} \mathrm{O}_{3}, \mathrm{MnO}_{2}, \mathrm{MnO}_{2}-\mathrm{C}$ and $\mathrm{CeO}_{2}$ can act as good electrocatalytic electrode materials for fuel oxidation [8, 9, 1921].

Nickel is an inexpensive and valuable electrocatalytic material for the oxidation of organic compounds, such as carbohydrates, and alcohols, such as ethanol, methanol, etc. [22-27]. Ethanol electro-oxidation using nickel or its alloys has been widely accepted in fuel cell development. A nickel redox couple, i.e., nickel hydroxide $\left(\mathrm{Ni}(\mathrm{OH})_{2}\right)$ and nickel oxyhydroxide $(\mathrm{NiOOH})$, was involved in alcohol oxidation at nickel electrodes in alkaline media $[5,12,22]$. It was found 
that $\mathrm{Ni}$ addition to $\mathrm{Pd}$ or $\mathrm{Pt}$ as $\mathrm{Ni}(\mathrm{OH})_{2} / \mathrm{NiOOH}$ improves the apparent electro catalytic activity of the electrode in ethanol.

There are many technologies for the development of nickel electrodes for ethanol oxidation in DEFC, such as chemical vapor deposition (CVD), sol-gel method, template method, hydrothermal method and electrochemical deposition method, etc. Among these methods, electrochemical deposition is far superior, due to the fact that the deposit morphology, size and shape can be precisely controlled by the variation of potential, current density, electrolyte composition, $\mathrm{pH}$ and temperature $[21,28]$. The electro synthesis process normally occurs at low temperatures (below $100{ }^{\circ} \mathrm{C}$ ), not requiring sophisticated high budget equipment. Nano deposition and thin film crystalline structure can be obtained [21, 29-31]. Metals or metal oxides can be electrodeposited at anode or cathode from their ions, at the right deposition potential and control of current. The deposition potential is expressed by the following equation (see also Fig. 1).

$$
\mathrm{E}=\mathrm{E}_{e q}+\eta_{a c t}+\eta_{c o n c}+\mathrm{IR} \text { electrolyte }
$$

where $E_{\text {eq }}$ is the equilibrium potential, $\eta_{\text {act }}$ is the overvoltage due to the electrode polarization, $\eta_{\text {conc }}$ is the overvoltage due to concentration polarization or mass transfer process by diffusion through the electrolyte, and IR is the current and the resistance, respectively, due to the electrolyte resistance.

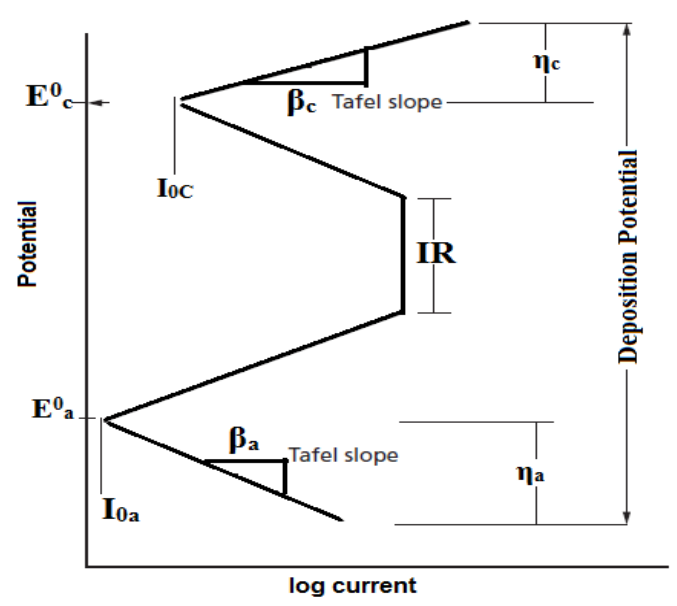

Figure 1. Polarization activation [34].

In the pulse current electrodeposition process, there are two important parameters present, i.e., relaxation time $\left(\mathrm{T}_{\text {off }}\right)$ and pulse time $\left(\mathrm{T}_{o n}\right)$, of which values can be effectively optimized (Fig. 2). Each pulse consists of $\mathrm{T}_{o n}$, during which the potential or the current is applied, and of $\mathrm{T}_{\text {off, }}$ during which the zero current is applied. Hence, duty cycle may be expressed as: $\frac{\text { Ton }}{\text { Ton+Toff }}=f . \mathrm{T}_{\text {on }}$, where $f$ is the pulse frequency $[32,33]$. 


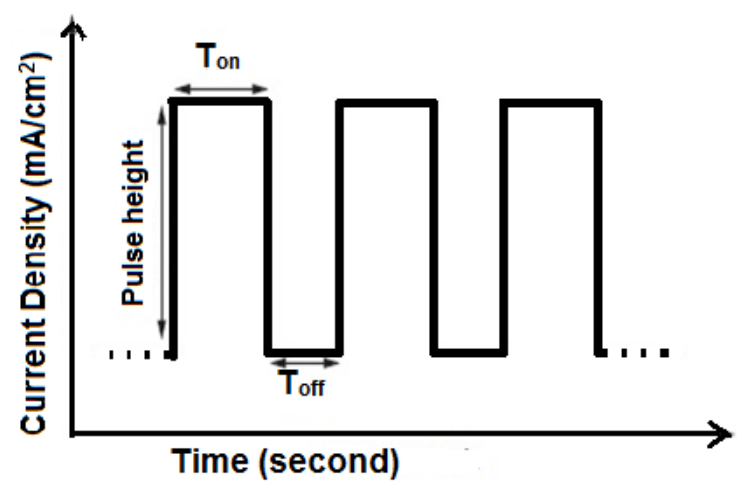

Figure 2. Pulse current deposition.

The electrocatalytic activity and the surface morphology of the electrodeposited nickel depend on several factors, such as electrolyte bath composition, deposition potential, current density, time, temperature, additive, $\mathrm{pH}$, etc. [28, 35-38]. Different electrolytic solutions, such as sulphate, chloride, boric acid, etc., are used for nickel electrodeposition. Nickel sulphate increases the solution conductivity, and determines the limiting cathode current density for producing a fine nickel deposit. Nickel chloride enhances the solution conductivity, throwing power and coating uniformity, whereas boric acid is used for buffer purposes, to maintain the electrolyte's $\mathrm{pH}$. The solution's $\mathrm{pH}$ was found to play an important role on the crystallite size. A pH in the range of 4.6 to 5.0 has been established to result in the finest crystallite size [30, 37]. Ebrahimi F. et al. [35], and Mustapha Boubatra et al. [36] have reported that the deposit's grain size increases, due to a reduction in the nucleation rate at a high $\mathrm{pH}$. The higher is the nucleation rate during deposition, the finer are the deposits' crystal grains.

In the present paper, nickel was electro-chemically deposited on the copper foil using direct current (DC) and pulse current (PC), varying depositing potential, time, and temperature in acidic media. Nickel sulphate, nickel chloride and boric acid solutions were used as electrolytes. The presence of electro deposited nickel was confirmed by XRD, EDXA, and the coating surface morphology was revealed by scanning electron microscope (SEM). Electrocatalytic activities of the developed materials towards ethanol electro oxidation were characterized by cyclic voltammetry (CV), chronoamperometry (CA), and potentiodynamic polarization tests.

\section{Experimental}

A Cu-foil with the surface area of $1 \times 1 \mathrm{~cm}^{2}$ was polished by emery papers, degreased by acetone, washed in distilled water and dried. Electro depositions of nickel (Ni) on copper were carried out by a DY 2300 potentiostat, using direct current (DC) and pulse current (PC). For the nickel coating, the electrolyte solution was $0.5 \mathrm{M} \mathrm{NiCl}_{2} .6 \mathrm{H}_{2} \mathrm{O}, 0.25 \mathrm{M} \mathrm{NiSO}_{4} .6 \mathrm{H}_{2} \mathrm{O}$, and $0.5 \mathrm{M} \mathrm{H}_{3} \mathrm{BO}_{3}$. A preselection of different coating potentials was done by a potentiodynamic test in the depositing solution. The parameters for each test are shown in Table 1. The X-ray diffraction technique was carried out using Rigaku Ultima III X-ray diffraction to map the crystalline structure and crystalline phase in each coated 
surface. The test was done with the monochromatic $\mathrm{Cu} \mathrm{K}_{\alpha}$ radiation at room temperature, at a scan rate of $2 \% \mathrm{~min}$. The crystallographic planes of X-ray diffraction were obtained from the inbuilt software of the X-ray machine. The surface morphology and particle distribution of the electrodeposited composite coatings were performed by using a Scanning Electron Microscope (SEM) (JEOL -JSM 6360). The presence of electrodeposited Ni particles was evaluated by using EDXA fitted with a Scanning Electron Microscope (JEOL -JSM 6360).

Table 1. Electrode deposition parameters for $\mathrm{Ni}$ coating on a $\mathrm{Cu}$ surface.

\begin{tabular}{|c|c|c|c|}
\hline \multicolumn{2}{|c|}{ Varied potential (V vs. SCE) } & Temperature & Optimum pH \\
\hline \multicolumn{2}{|c|}{$-0.31 \mathrm{~V},-0.37 \mathrm{~V},-0.6 \mathrm{~V}$} & $25^{\circ} \mathrm{C}, 40^{\circ} \mathrm{C}, 65^{\circ} \mathrm{C}$ & 4 \\
\hline & $\begin{array}{c}\text { Direct/ Pulse deposition } \\
\text { time }\left(\mathbf{T}_{\text {on }}\right)\end{array}$ & $\begin{array}{c}\text { Relaxation time } \\
\left(\mathbf{T}_{\text {off }}\right)\end{array}$ & Total deposition time \\
\hline Direct current & $150 \mathrm{sec}, 240 \mathrm{sec}, 360 \mathrm{sec}$ & - & $150 \mathrm{sec}, 240 \mathrm{sec}, 360 \mathrm{sec}$ \\
\hline Pulse current & $5 \mathrm{sec}$ & $20 \mathrm{sec}$ & $150 \mathrm{sec}, 240 \mathrm{sec}, 360 \mathrm{sec}$ \\
\hline
\end{tabular}

\section{Electrochemical characterization}

The performance of the developed electro catalytic Ni-Cu coated sample by DC and $\mathrm{PC}$ was done in $1 \mathrm{M} \mathrm{KOH}+1 \mathrm{M}$ ethanol solution, $\mathrm{pH} 13.1$, by cyclic voltammetry, chronoamperometry, and potentiodynamic polarization tests. Cyclic voltammetry of the electroplated sample was performed in a computer controlled electrochemical system machine, DY 2300 potentiostat, with a threeelectrode system. Potential was scanned from $-1.3 \mathrm{~V}$ vs. SCE to 0.3 vs. SCE, with a scan rate of $50 \mathrm{mV} / \mathrm{second}$ to find out $\mathrm{I}_{\max }$ (current amplitude). Here, graphite rod was taken as counter electrode, saturated calomel electrode as reference electrode, and the test sample as working electrode. Chronoamperometry (I vs. t) was tested in the same machine with different software. The experiment was carried out at different fixed potentials selected around the ethanol oxidation potential, as shown in the equation (1). The current (I) was monitored as a function of time (t), to find out for how long current was delivered from the cell. The potentiodynamic polarization test was conducted with a three-electrode system, as stated above, and the electro kinetic parameter, exchange current density $\left(I_{0}\right)$, was determined from the polarization curve. The potential was scanned between $-1 \mathrm{~V}$ and $0.5 \mathrm{~V}$ vs. SCE, at a scan rate of 1 $\mathrm{mV} / \mathrm{second}$.

\section{Results and discussion}

The present investigation is aimed at developing high electrocatalytic $\mathrm{Ni}-\mathrm{Cu}$ electrodes by nickel electrodeposition from $\mathrm{Ni}$-salt on $\mathrm{Cu}$. The morphology of the electrodeposited material is very important, as it decides the charge-discharge reaction rate on fuel oxidation over the electrocatalytic material. The electrosynthesized substrate morphology is strongly influenced by the deposition potential and the current, along with the electrolyte chemistry. To understand and find the electrodeposition potential effect on the electro catalytic properties, a 
polarization experiment has been conducted using a $\mathrm{Cu}$ substrate in $\mathrm{a} \mathrm{Ni}^{+2}$ solution. Nickel is deposited in the curve's cathodic polarization region, as shown in Fig. 3. Three preselected deposition potentials were: (i) before the start of Tafel region, i.e., $-0.31 \mathrm{~V}$ vs. SCE; (ii) at the end of Tafel region, i.e., $-0.37 \mathrm{~V}$ vs. SCE; and (iii) in the polarization concentration region or mass control process, i.e., $-0.6 \mathrm{~V}$ vs. SCE. The Tafel region has been magnified and shown inside Fig. 3. It is to be noted that the potential $-0.31 \mathrm{~V}$ to $-0.37 \mathrm{~V}$ is the charge transfer process region (valid Tafel law), and the third potential (i.e., -0.6 V vs. $\mathrm{SCE}$ ) is the potential controlled by mass transfer. The electrodeposition has been carried out by two techniques: direct current (DC) and pulse current (PC) coating. During the direct current coating, if the process is mass controlled, then the deposition may slow down, whenever the metal ions are not available in the electrode surface vicinity. Thus, in pulse current coating technique, a time off ( $\left.\mathrm{T}_{\text {off }}\right)$ is given, when the metal ions in the bulk take some time to diffuse through the solution and reach the electrode surface. During $\mathrm{T}_{\mathrm{on}}$, the current is passed,

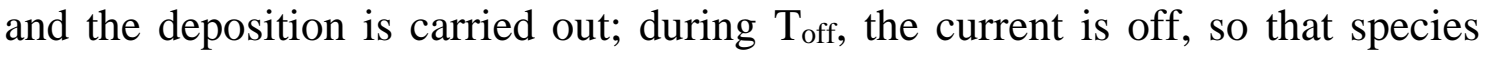
take more time to reach the electrode surface for deposition.

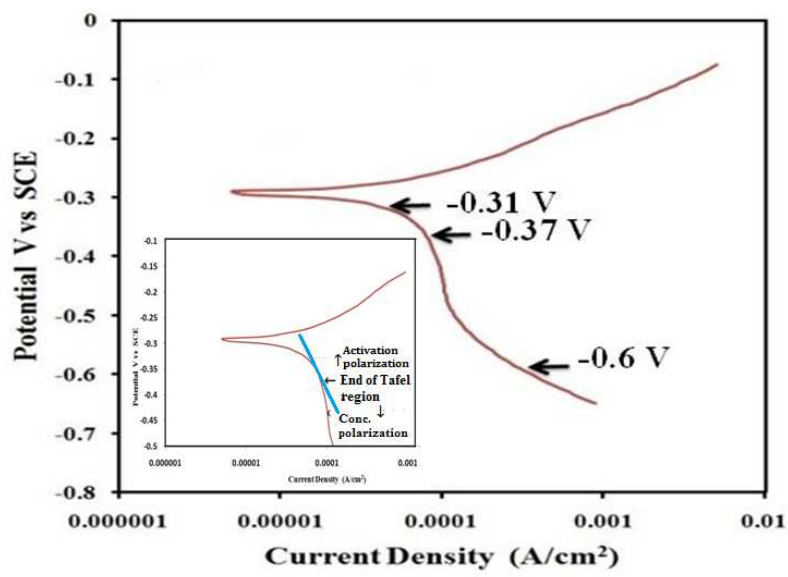

Figure 3. Potentiodynamic polarization test to select the Ni potential for deposition on a $\mathrm{Cu}$ foil.

\section{Performance of electro-synthesized $\mathrm{Ni}$-Cu by electrochemical techniques}

Once the electrode has been synthesized by deposition techniques, it needs to be electrochemically characterized in a fuel solution such as ethanol, to find how well the $\mathrm{Ni}-\mathrm{Cu}$ electro-catalytic material has been developed. The electrochemical characterizations are done by cyclic voltammetry (CV), chronoamperometry (CA) and potentiodynamic (PD) polarization tests, which are discussed in the following section.

\section{Cyclic voltammetry study}

The cyclic voltammetry studies are shown in Fig. 4(A) and 4(B), for DC and PC coating at potential of $-0.31 \mathrm{~V}$ vs. SCE (see Fig. 3), respectively.

The other variations are deposition time and temperature at the electrolyte fixed chemistry. It is seen that, for the entire curve, there are current peaks around some fixed potentials. However, the third current peak has been considered to be 
due to fuel electro oxidation. The other peaks are due to the intermediate state of fuel electro oxidation. The values of current peaks under the electrodeposition condition are shown in Table 2. Similar figures are given in 4(C), 4(D), 4(E) and 4(F) for the samples synthesized at the potentials of $-0.37 \mathrm{~V},-0.6 \mathrm{~V}$ vs. SCE, using direct and pulse current coating, respectively. It is to be noted that there is a strong deposition potential effect.
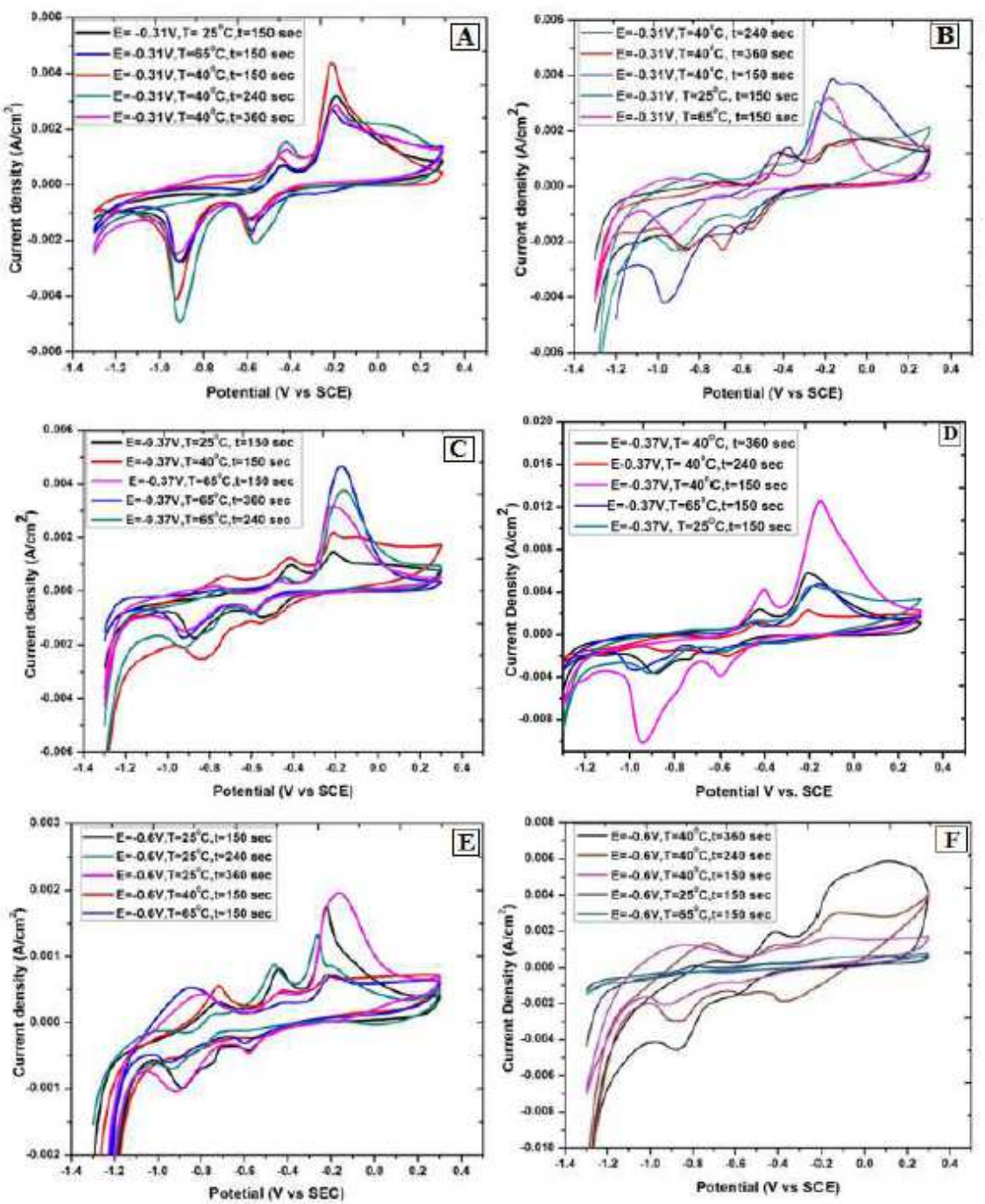

Figure 4. Cyclic voltammetry of $\mathrm{Ni}-\mathrm{Cu}$ electrodes in $1 \mathrm{M}$ ethanol in $1 \mathrm{M} \mathrm{KOH}$; (A), (C), (E) at potentials $-0.31 \mathrm{~V},-0.37 \mathrm{~V}$ and $-0.6 \mathrm{~V}$ vs. SCE, using direct current; (B), (D), (F) at potentials $-0.31 \mathrm{~V},-0.37 \mathrm{~V}$ and $-0.6 \mathrm{~V}$ vs. SCE, using pulse current, respectively.

It is seen that the potential of $-0.37 \mathrm{~V}$ vs. SCE, which is right at the end of Tafel region, has produced an electrodeposited $\mathrm{Ni}-\mathrm{Cu}$ substrate that gives the highest current density, keeping the temperature and deposition time fixed (Table 2). This table shows that the sample electro synthesized at the end of Tafel region potential (charge transfer oxidation) produces an electrocatalytic material of superior quality, with the highest current density on the ethanol electro oxidation. Of the two modes, direct and pulse current coating at the same potential, i.e., $-0.37 \mathrm{~V}$ vs. SCE, it is seen that the electrode material produced by pulse coating has given a much higher current of about $12.4 \mathrm{~mA} / \mathrm{cm}^{2}$, compared to that of 2.25 
$\mathrm{mA} / \mathrm{cm}^{2}$ in DC mode. Thus, as it produces a high energetic electrocatalytic material, the pulse coating is stronger, and the deposition potential should be preselected from the polarization curve at the end of Tafel region, in the deposition solution.

Table 2. Cyclic voltammetry data of $\mathrm{Ni}-\mathrm{Cu}$ electrodes synthesized at different potentials.

\begin{tabular}{|c|c|c|c|c|c|}
\hline $\begin{array}{c}\text { Potential } \\
\text { (Volt vs. SCE) }\end{array}$ & $\begin{array}{c}\text { Temperature } \\
\left({ }^{\circ} \mathrm{C}\right)\end{array}$ & $\begin{array}{c}\text { Time } \\
\text { (second) }\end{array}$ & $\begin{array}{c}\text { Peak potential } \\
\text { (Volt) }\end{array}$ & $\begin{array}{c}\text { Peak current } \\
\text { density } \\
\left(\mathbf{m A} / \mathbf{c m}^{2}\right)\end{array}$ & $\begin{array}{c}\text { Imax at } 0.3 \\
\text { Volt } \\
\left(\mathbf{m A} / \mathbf{c m}^{2}\right)\end{array}$ \\
\hline \multirow{5}{*}{$\begin{array}{c}-0.31 \text { Volt } \\
\text { DC }\end{array}$} & 40 & 360 & -0.194 & 2.83 & 1.28 \\
\hline & 40 & 240 & -0.193 & 2.86 & 1.25 \\
\hline & 40 & 150 & -0.211 & 4.2 & 0.478 \\
\hline & 25 & 150 & -0.193 & 3.2 & 0.883 \\
\hline & 65 & 150 & -0.207 & 2.7 & 1.41 \\
\hline \multirow{5}{*}{$\begin{array}{c}-0.31 \text { Volt } \\
\text { PC }\end{array}$} & 40 & 360 & 0.193 & 1.55 & 1.46 \\
\hline & 40 & 240 & -0.066 & 1.72 & 1.25 \\
\hline & 40 & 150 & -0.177 & 3.7 & 1.3 \\
\hline & 25 & 150 & -0.180 & 3.2 & 0.477 \\
\hline & 65 & 150 & -0.242 & 3.05 & 2.1 \\
\hline \multirow{6}{*}{$\begin{array}{c}-\mathbf{- 0 . 3 7} \text { Volt } \\
\text { DC }\end{array}$} & 65 & 360 & -0.221 & 3.2 & 0.59 \\
\hline & 65 & 240 & -0.169 & 3.8 & 1.02 \\
\hline & 65 & 150 & -0.177 & 4.72 & 0.35 \\
\hline & 65 & 60 & -0.132 & 4.06 & 2.38 \\
\hline & 40 & 150 & -0.213 & 2.25 & 1.75 \\
\hline & 25 & 150 & -0.210 & 1.54 & 0.808 \\
\hline \multirow{5}{*}{$\begin{array}{c}-\mathbf{- 0 . 3 7} \text { Volt } \\
\text { PC }\end{array}$} & 40 & 360 & -0.209 & 5.86 & 1.12 \\
\hline & 40 & 240 & 0.213 & 2.7 & 2.02 \\
\hline & 40 & 150 & -0.162 & 12.4 & 1.44 \\
\hline & 25 & 150 & -0.192 & 4.5 & 3.4 \\
\hline & 65 & 150 & -0.165 & 4.74 & 1.64 \\
\hline \multirow{5}{*}{$\begin{array}{c}-0.6 \text { Volt } \\
\text { DC }\end{array}$} & 25 & 360 & -0.163 & 1.98 & 0.716 \\
\hline & 25 & 240 & -0.263 & 1.34 & 0.544 \\
\hline & 25 & 150 & -0.221 & 1.74 & 0.428 \\
\hline & 40 & 150 & -0.222 & 0.738 & 0.713 \\
\hline & 65 & 150 & -0.196 & 0.744 & 0.661 \\
\hline \multirow{5}{*}{$\begin{array}{l}-0.6 \text { Volt } \\
\text { PC }\end{array}$} & 40 & 360 & -0.122 & 5.01 & 4.08 \\
\hline & 40 & 240 & -0.156 & 3.05 & 4.02 \\
\hline & 40 & 150 & -0.173 & 1.64 & 1.71 \\
\hline & 25 & 150 & -0.082 & 0.602 & 0.632 \\
\hline & 65 & 150 & -0.117 & 0.568 & 0.767 \\
\hline
\end{tabular}

The temperature effect was found to be intermediate, when the current produced by ethanol electrochemical oxidation was the highest. For example, at $-0.31 \mathrm{~V}$ vs. SCE, a sample deposited at $40^{\circ} \mathrm{C}$ gives much higher current than the samples produced at higher or lower temperatures. The higher is the temperature, the greater is the convective mass transfer that makes more $\mathrm{M}^{+}$ions available at the electrode surface. Secondly, at higher temperatures, the electrolyte conductivity is high, so the polarization resistivity to deposition is low. However, at higher temperatures, solids' electronic conductivity is low. Due to this, there may be some decrease in electron charge density on the electrode surface, due to the temperature rise. 

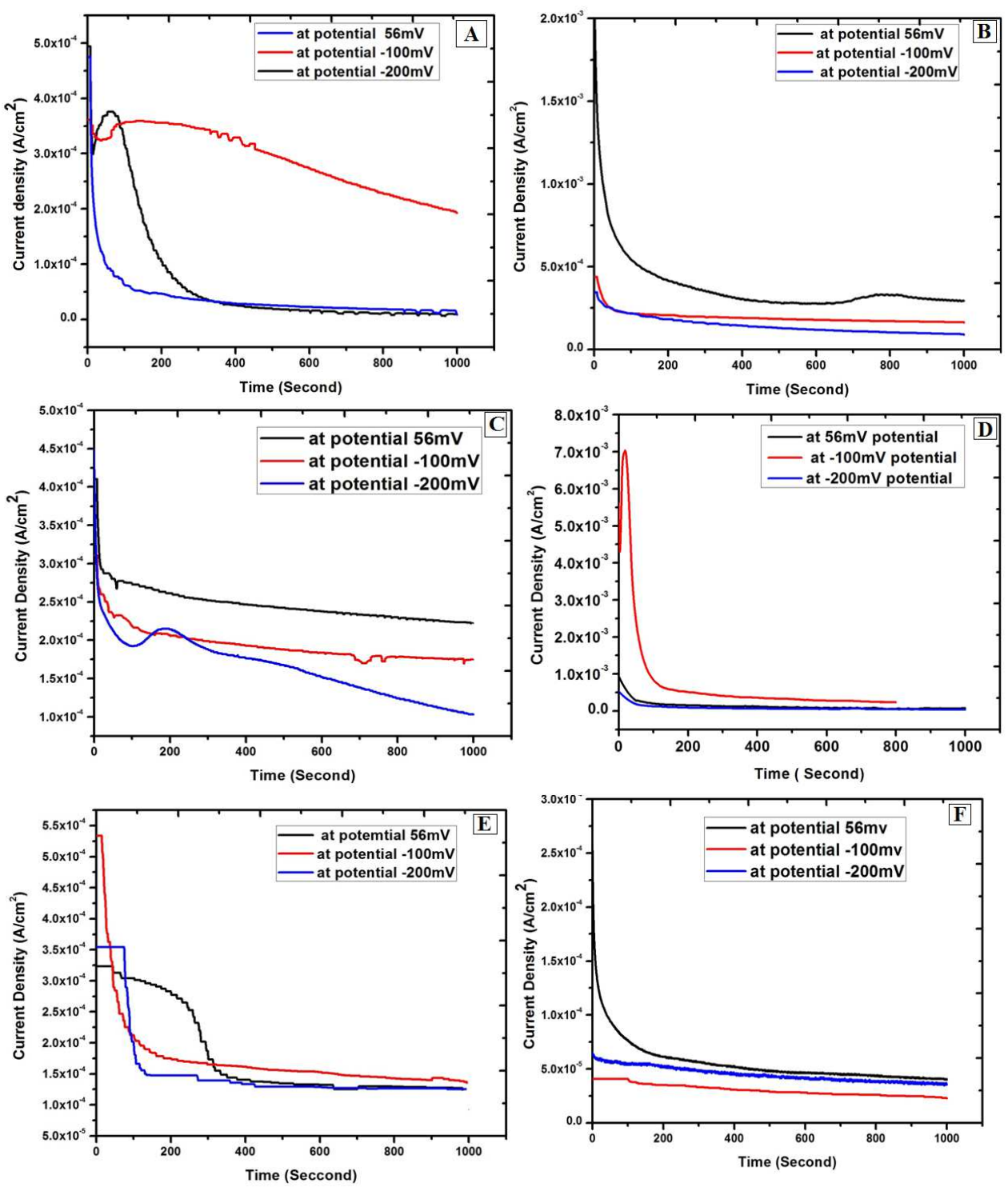

Figure 5. Chronoamperometry of $\mathrm{Ni}-\mathrm{Cu}$ electrode in $1 \mathrm{M}$ ethanol in $1 \mathrm{M} \mathrm{KOH}$ at different potentials; $(\mathrm{A}),(\mathrm{C}),(\mathrm{E})$ at potentials $-0.31 \mathrm{~V},-0.37 \mathrm{~V}$ and $-0.6 \mathrm{~V}$ vs. SCE, using direct current; (B), (D), (F) at potentials $-0.31 \mathrm{~V},-0.37 \mathrm{~V}$ and $-0.6 \mathrm{~V}$ vs. SCE, using pulse current, respectively.

\section{Chronoamperometry study}

The variation of current with time (I vs. t), at a fixed potential on ethanol electro oxidation, over that developed $\mathrm{Ni}-\mathrm{Cu}$ electrode at three pre-selected electro synthesized potentials (Fig. 4), is shown in Fig. 5 (A-F). The studies were made at different fixed potentials, i.e., $56 \mathrm{mV},-100 \mathrm{mV}$ and $-200 \mathrm{mV}$, which are near the region of fuel oxidation potentials, as found by cyclic voltammetry. It is seen that, in most of the curves, there is an initial drop of some current, after which a steady state current is obtained. Fig. 5 A, C and E shows the electrodes produced by direct current coating, whereas Fig. $5 \mathrm{~B}, \mathrm{D}$ and $\mathrm{F}$ shows the ones produced by pulse current at potentials $-0.31 \mathrm{~V},-0.37 \mathrm{~V}$ and $-0.6 \mathrm{~V}$, respectively. The steady state current obtained on the electrode surface produced by pulse current has been found to be higher than the steady state current from the electrode 
surface produced by direct current coating. For example, at $-100 \mathrm{mV}$ potential, the steady state current is about $1 \mathrm{~mA} / \mathrm{cm}^{2}$ for pulse coated material at $-0.37 \mathrm{~V}$ vs. SCE, whereas for direct current coating, it is about $0.25 \mathrm{~mA} / \mathrm{cm}^{2}$ under similar conditions. So, the chronoamperometry study also shows that electrodes produced by pulse current have better electrocatalytic properties than the ones produced by simple direct current coating.

\section{Potentiodynamic polarization study}

Potentiodynamic polarizations tests were also carried out for better understanding the electrocatalytic properties of the produced electrode. These are shown in Fig. 6 A, C, E for direct current coating, and Fig. 6 B, D, F for pulse coated electrode at potentials $-0.31 \mathrm{~V},-0.37 \mathrm{~V}$ and $-0.6 \mathrm{~V}$, respectively.
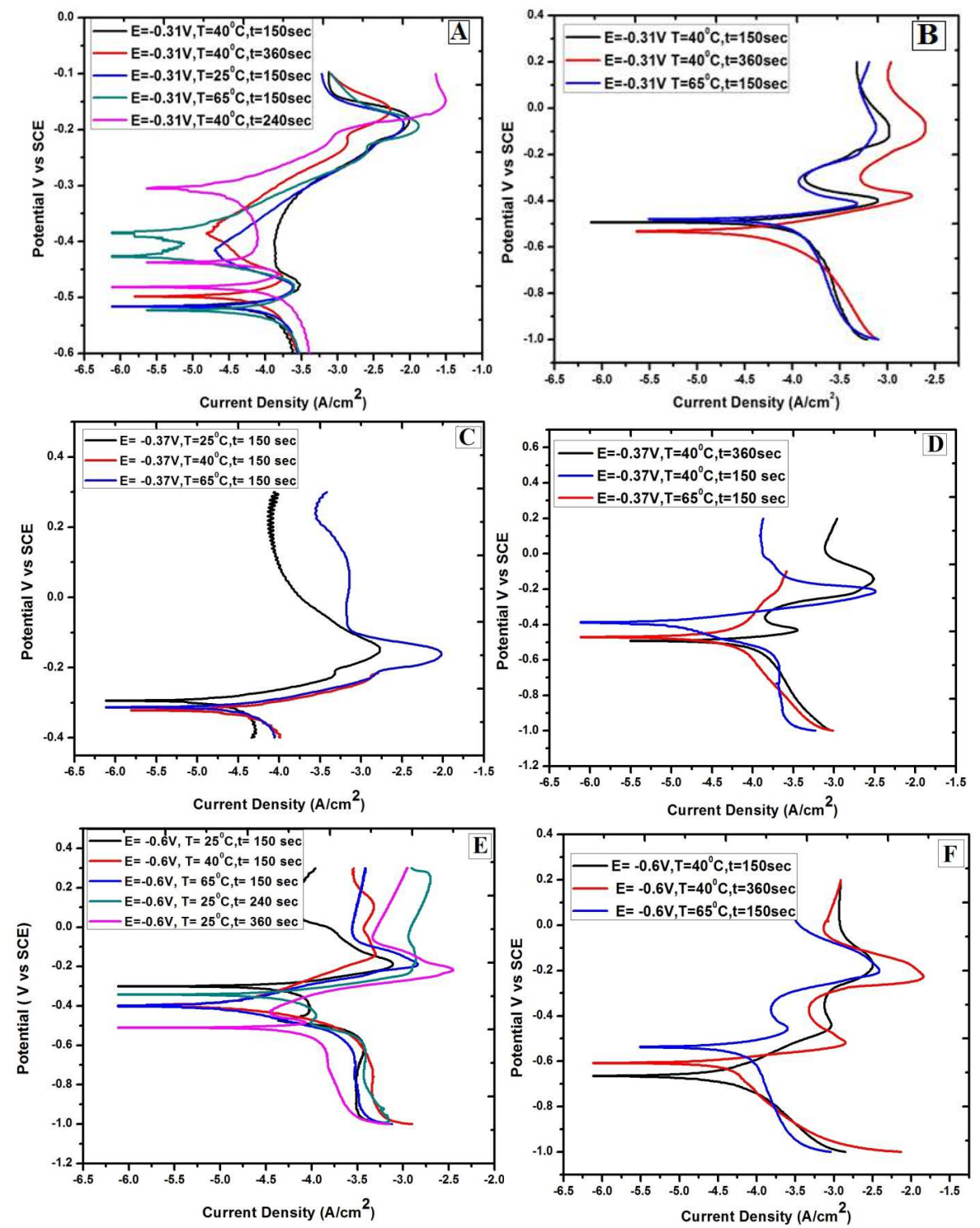

Figure 6. Potentiodynamic polarization curves of $\mathrm{Ni}-\mathrm{Cu}$ electrode in $1 \mathrm{M}$ ethanol in 1 $\mathrm{M} \mathrm{KOH}$ at different potentials; (A), (C), (E) at potentials $-0.31 \mathrm{~V},-0.37 \mathrm{~V}$ and $-0.6 \mathrm{~V}$ vs. SCE, using direct current; (B), (D), (F) at potentials $-0.31 \mathrm{~V},-0.37 \mathrm{~V}$ and $-0.6 \mathrm{~V}$ vs. SCE, using pulse current, respectively. 
The computed electrokinetic data, such as exchange current density, which is highly influenced by the morphology of the electrocatalytic substrate, are illustrated in Fig. 7 (A-F). From Fig. 7 (A-F), it is found that there is a direct relation between exchange current density and maximum current density. It is seen that the polarization data also support the results of cyclic voltammetry and chronoamperometry studies. The highest exchange current density has been obtained (Fig. 7 (D)) for the electrode produced by pulse current electrode potential at pre-selected $-0.37 \mathrm{~V}$ vs. SCE.
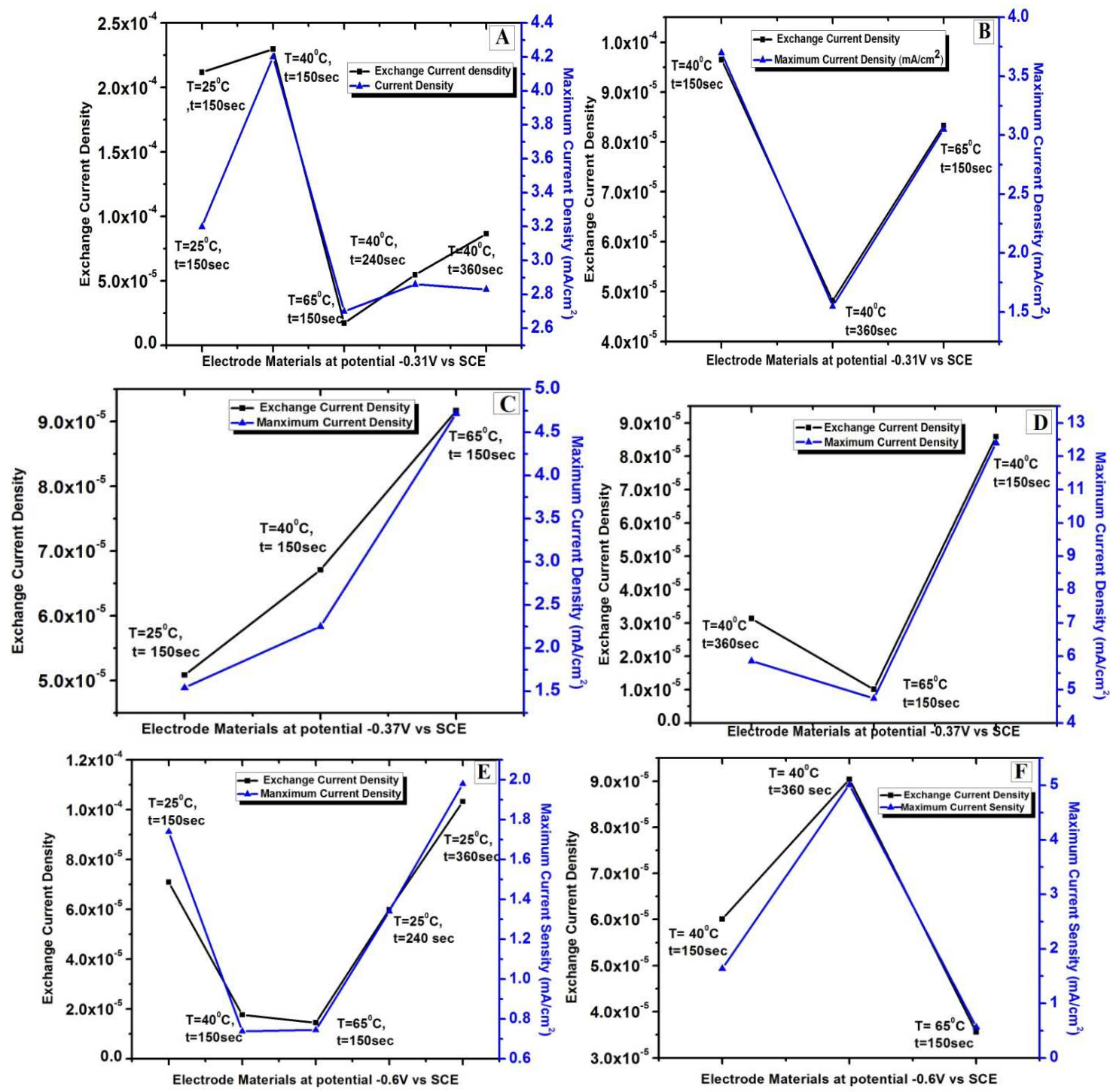

Figure 7. Comparison between exchange current density and highest peak current density of the electrode produced at different potentials; (A), (C), (E) at potentials -0.31 $\mathrm{V},-0.37 \mathrm{~V}$ and $-0.6 \mathrm{~V}$ vs. SCE, using direct current; (B), (D), (F) at potentials $-0.31 \mathrm{~V}$, $-0.37 \mathrm{~V}$ and $-0.6 \mathrm{~V}$ vs. SCE, using pulse current, respectively.

So, it can be concluded that the electrode surface morphology produced by electrode deposition technique is influenced by the coating mode, direct current or pulse current, as well as by the deposition potential. The best electrocatalytic material can be produced by selecting a deposition potential on the cathodic 
polarization curve of the material, to be electrodeposited in the solution, at a point right at the end of the Tafel region.

\section{Material characterization}

For better understanding the effect of electrodeposition parameters, as studied in the previous sections, the electrode materials were characterized by XRD, EDXA, and the surface morphology was visualized under scanning electron microscope (SEM).

Fig. 8 (A-B) shows the XRD patterns of the electrodeposited $\mathrm{Ni}-\mathrm{Cu}$ electrode, using direct and pulse current coating. It shows the presence of $\mathrm{Cu}$ and $\mathrm{Ni}$ in both the figures. $\mathrm{Cu}$ acts as substrate, as well as electrode, and $\mathrm{Ni}$ purely acts as electrode. That is why peak intensity for $\mathrm{Cu}$ is always higher than for $\mathrm{Ni}$. The effect of electrodeposition potentials' change from $-0.31 \mathrm{~V}$ to $-0.6 \mathrm{~V}$ vs. SCE is clearly visible in XRD. According to Scherrer formula, the width of the peak is inversely proportional to the grain size of the coated material. It is found that the width of the Ni deposited in the pulse current coating is wider than in the direct current.
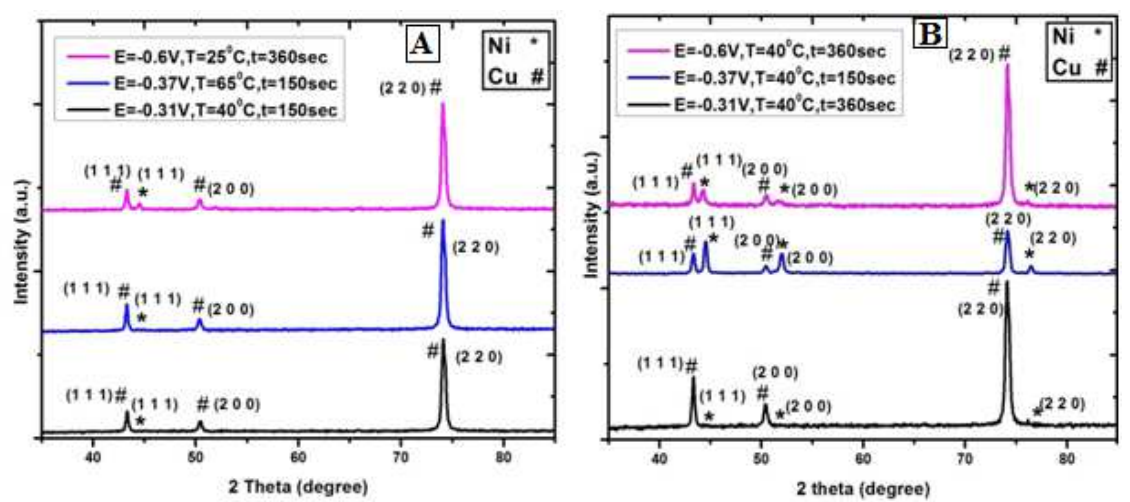

Figure 8. XRD patterns of Ni-Cu using (A) direct current and (B) pulse current.

\section{EDXA study}

Fig. 9 (A-F) shows the EDXA of direct and pulse coated materials which exhibit both the presence of $\mathrm{Ni}$ and $\mathrm{Cu}$. This suggests that $\mathrm{Cu}$ not only acts as current collector, but also as electrode with $\mathrm{Ni}$, in all the studies.

\section{SEM micrographs}

It is to be noted from SEM images (Fig. $10 \mathrm{~A}-\mathrm{F}$ ) that the globular form of the precipitation, which increases the effective surface area for electro oxidation, has been enhanced with an increase in the coating deposition potential. If the morphologies of the coating deposited by direct coating and pulse coating are compared, it is found that there are channels and recesses in between the grains on the surface of the coated material deposited by pulse current coating, whereas overall grain size of the direct current coating is somewhat smaller than to that deposited by pulse coating. The current produced by ethanol electro oxidation on the electro deposited electrode is strongly influenced by the amount of real surface available at the atomic level. The more fine is the deposited grain, the wider is the surface area for the charge-discharge reaction. At the same time, the 
greater is the number of channels and inter-channels and recesses within the grains, the higher is the area for the charge-discharge reaction, leading to higher current delivery. It is thought that an increase in surface area, due to the generation of channels and inter-channels in 3D, is much greater than the increase in the area due to finer grain size. This may be the reason for obtaining a higher current during ethanol electrochemical oxidation on the electrode surface, produced by pulse current coating, than that produced by direct current coating.
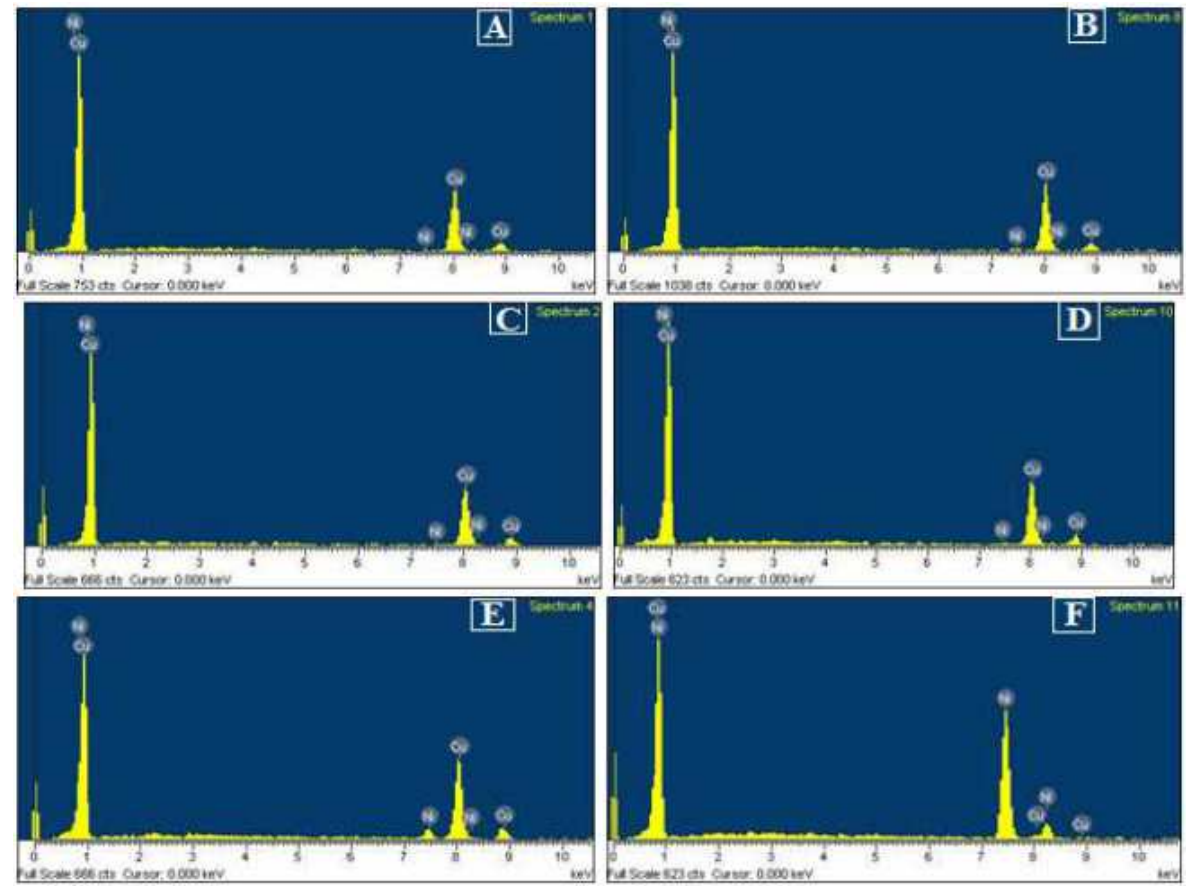

Figure 9. EDXA of Ni-Cu electrode. (A), (C), (E) at potentials $-0.31 \mathrm{~V},-0.37 \mathrm{~V}$ and $-0.6 \mathrm{~V}$ vs. SCE, using direct current; (B), (D), (F) at potentials $-0.31 \mathrm{~V},-0.37 \mathrm{~V}$ and $-0.6 \mathrm{~V}$ vs. SCE, using pulse current, respectively. $-0.31 \mathrm{~V} \mathrm{DC}$ and PC.

\section{Conclusion}

From the foregoing results and discussion, it is found that $\mathrm{Ni}-\mathrm{Cu}$ electrodes have been successfully synthesized by direct and pulse current coating techniques for ethanol electro oxidation. The surface morphology and electrocatalytic activity of this electrode material are strongly influenced by the right selection of deposition potential, as well as by the deposition mode, i.e., pulse current or direct current coating and temperature. The current delivered by ethanol oxidation is much higher over the electrodes, which is synthesized by pulse current at the preselected deposition potential, just at the end of the Tafel region, compared to the current produced over the electrodes by DC coating, under similar conditions. $\mathrm{Cu}-\mathrm{Ni}$ electrodeposited material synthesized by the pulse current technique has produced a high energetic electrocatalytic material with high exchange current density and the highest cell current. 


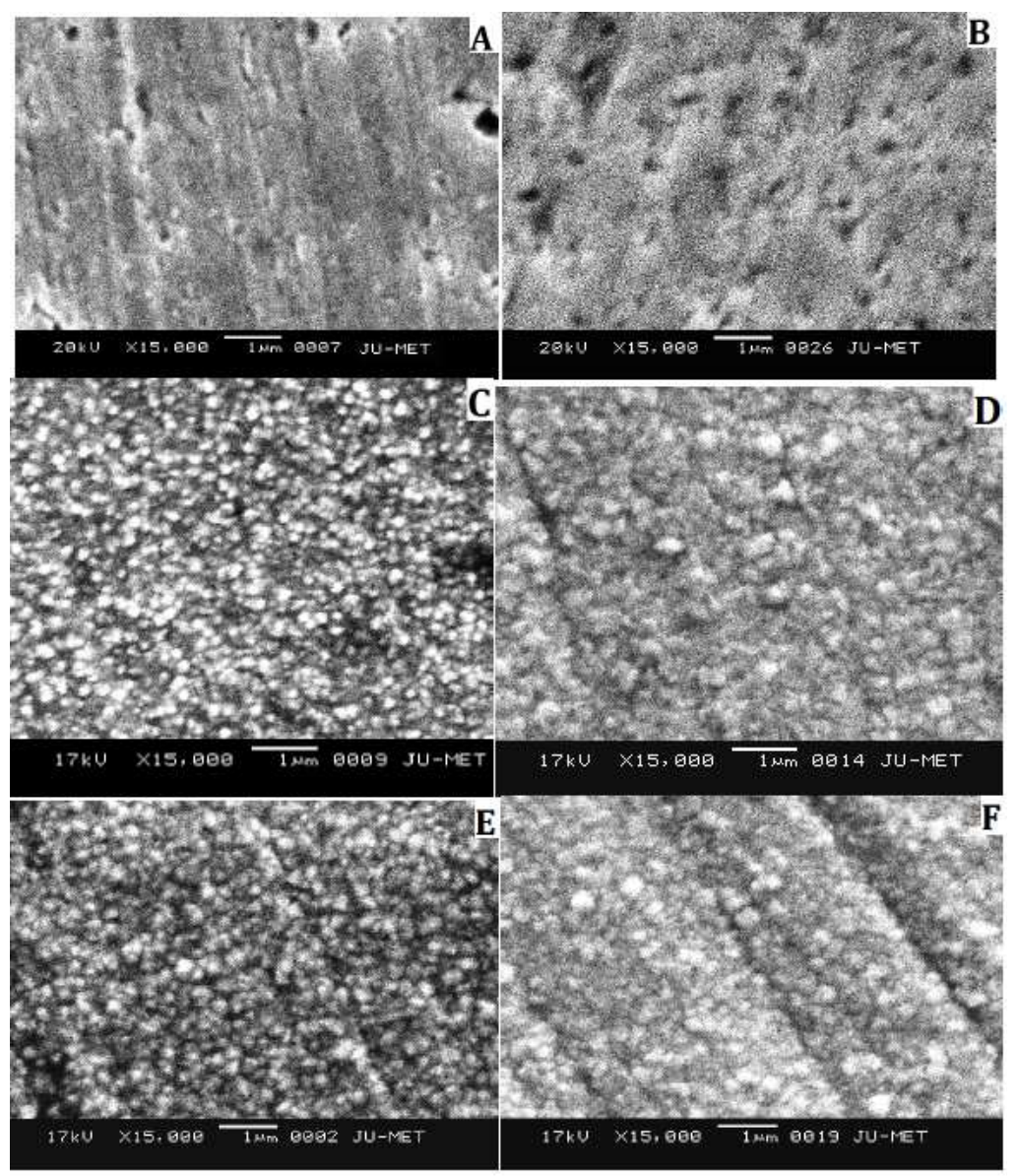

Figure 10. SEM morphology of Ni-Cu electrode. (A), (C), (E) at potentials $-0.31 \mathrm{~V}$, $-0.37 \mathrm{~V}$ and $-0.6 \mathrm{~V}$ vs. SCE, using direct current; (B), (D), (F) at potentials $-0.31 \mathrm{~V}$, $-0.37 \mathrm{~V}$ and $-0.6 \mathrm{~V}$ vs. SCE, using pulse current, respectively. $-0.31 \mathrm{~V}$ DC and PC.

\section{Acknowledgement}

The authors would like to acknowledge "TEQIP, COE Phase II", in Jadavpur University, for supporting this work.

\section{References}

1. Parson Inc. Fuel cell handbook. West Virginia: US Dept Energy; 2000.

2. Xu C, Shen PK, Liu Y. J Power Sources. 2007; 164:527-531.

3. Andreadis G, Song SQ, Tsiakaras P. J Power Sources. 2006;157:657-665.

4. Rousseau S, Coutanceau C, Lamy C, et al. J Power Sources. 2006;158:18-24.

5. Wang ZB, Yin GP, Zhang J, et al. J. Power Sources. 2006;160:37-43.

6. Song SQ, Tsiakaras T. Appl Catalysis B: Environ. 2006;63:187-193.

7. Paul S. J Fuel Cell Sci. Technol. 2012;9:021013.

8. Guchhait SK, Paul S. Int J Renew Energy Research. 2016;6:723-734.

9. Guchhait SK, Paul S. J Electrochem Sci Technol. 2016;7:190-198.

10. Hu F, Chen C, Wang Z, et al. Electrochem Acta. 2006;52:1087-1091.

11. Shen SY, Zhao TS, Xu JB, et al. J Power Sources. 2010;195:1001-1006.

12. Paul S. Nanomater Energy. 2015;4:80-89. 
13. Huang J-J, Hwang W-S, Weng Y-C, et al. 2009;50:1139-1147.

14. Scibioh MA, Kim S-K, Cho EA, et al. Appl Catalysis B: Environ. 2008;84:773-782.

15. Wang X-Y, Zhang J-C, Cao X-D, et al. Int J Minerals, Metallurgy Mater. 2011;18:594-599.

16. Paul S, Naimuddin SK. J Fuel Chem Technol. 2015;12:011007.

17. Singh RN, Singh A, Anindita. Carbon. 2009;47:271-278.

18. Lamy C, Lima A, Rhun VL, et al. J. Power Sources. 2002;105:283-296.

19. Guchhait SK, Paul S. J Fuel Chem Technol. 2015;43:1004-1010.

20. Paul S, Ghosh A. J Fuel Chem Technol. 2015;43:344-351.

21. Paul S, Chatterjee R. Namomater Energy. 2015;3:1-9.

22. Hamdan MS, Nordin N, Amir SFM, et al. Sains Malaysiana. 2011;40:14211427.

23. Jafarian M, Mahjani MG, Heli H, et al. Electrochem Comm. 2003;5:184-188.

24. Yi Q, Zhang J, Huang W, Liu X. Catalysis Comm. 2007 ;8:1017-1022.

25. Mikołajczyk T, Turemko M, Pierożyński B. Polish J Chem Technol. 2015;17:47-50.

26. Riyanto, Othman MR, Salimon J. ASEAN J Sci Technol Develop. 2008;25:363-371.

27. Fleishmann M, Korinek K, Pletcher KD. J Electroanal Chem. 1971;31:39_ 49.

28. Sadiku-Agboola O, Sadiku ER, Ojo OI, et al. Port Electrochim Acta. 2011;29:91-100.

29. Aperador Chaparro WA, Lopez EV. Revista Matéria. 2007;12:583-588.

30. Glenn MO. J Electrochem. 1997;45:136-139.

31. Jelena BB. J Univ Belgrade. 2002;2:32-39.

32. Jegan A, Venkatesan R. Int J Minerals, Metallurgy, Mater. 2013;20:479-484.

33. Chandrasekar MS, Pushpavanam M. Electrochim Acta. 2008;53:3313-3322.

34. Paul S. Electrochemical energy synthesis and storage in battery and fuel cell. kindle publication; 2016.

35. Ebrahimi F, Ahmed Z. J Appl Electrochem. 2003;33:733-739.

36. Boubatra M, Azizi A, Schmerber G, et al. Ionics. 2012;18:425-432.

37. Rashidi AM, Amadeh A. J Mater Sci Technol. 2010;26:82-86.

38. Erb U. Nanostructured Mater. 1995;6:533-538. 